\title{
ULTRASTRUCTURE (SEM) OF THE GILLS OF PROCHILODUS SCROFA STEINDACHNER (PISCES, TELEOSTEI)
}

\author{
Daura Regina Eiras-Stofella ${ }^{1}$ \\ Patricia Charvet-Almeida ${ }^{2}$
}

\begin{abstract}
Gills arches of the freshwater fish Prochilodus scrofa Steindachner, $1881(\mathrm{Lt}=8.0-12.4 \mathrm{~cm})$ were removed to be analyzed in a scanning electron microscope. The morphology of the superficial structures of the gill filaments and pharyngeal region of the gills arches was discussed and related to their functional aspects. A great quantity of mucous secretory cells and of microridges, along with the pavement cell surface of the primary lamellae and branchial pharyngeal region, indicate the existence of a protection strategy of the respiratory lamellae. The chloride cells are abundant, specially on the distal portion of the primary lamellae, and bring out the osmo regulatory capacity of this species. This fish seems not to be a filtering one according to: its short and simple gill rakers; presence of several taste buds turned towards the mouth opening; evidence of spines on the external side of the arches and an abundant secretion of mucous in the pharyngeal region. This species probably selects the food to be swallowed through its chemical receptors and retains it with the help of spines and mucous secretion this way protecting the gills filaments against the rubbing of particles over them.
\end{abstract}

KEY WORDS. Gill morphology; scanning; freshwater fish; Prochilodus scrofa

Prochilodus scrofa Steindachner, 1881 is found in the South American continent, in freshwater of the South-Eastern Brazilian region and in Rio Paraguay and Rio Uruguay (GoDOY 1975).

Studies about fish gill morphology have been providing information mainly for the understanding of the respiratory processes and osmotic regulation (FISHELSON 1980; Hossler et al. 1986; FRANKLIN 1990; AVELLA et al. 1994; KUELTZ et al. 1995), and of food ingestion (EIRAS-STOFELla \& CHARVET-ALMEIDA 1997; MORAES et al. 1997).

In the present work the gill morphology of $P$. scrofa is described through scanning electron microscopy analysis. The functional aspects of the ultrastructures from the epithelial surfaces of the primary and respiratory lamellae and also of the branchial pharyngeal region are discussed. The morphology of the pharyngeal region and its rakers are also related to the feeding habit of this species.

1) Centro de Microscopia Eletrônica, Universidade Federal do Paraná. Caixa Postal 19031, 81530-900 Curitiba, Paraná, Brazil.

2) Caixa Postal 2632, 80001-970 Curitiba, Paraná, Brazil. 


\section{MATERIAL AND METHODS}

Ten $P$. scrofa $(\mathrm{Lt}=8.0-12.4 \mathrm{~cm})$ specimens were obtained from the water reservoir of the Usina Hidroelétrica Governador Parigot de Souza located on the Rio Ribeira Basin (Paraná, Brazil).

The gill arches were removed from the fish after it was submitted to anesthesia (MS-222). Special attention was given to the second branchial arch (BaII) which was isolated and washed in a $0.9 \% \mathrm{NaCl}$ solution. Later on, the BaII were fixed in $3 \%$ glutaraldehyde with $0.1 \mathrm{M}$ cacodylate buffer (1:1), washed in the same buffering solution, dehydrated in a graded ethanol series and reached critical point dehydration with the use of $\mathrm{CO}_{2}$. The samples were gold coated, observed and photographed in a scanning electron microscope (Philips SEM-505).

\section{RESULTS}

The BaII present a strong curvature angle on the superior third of the arch. This characteristic is more evident on the anterior portion of the arch, that is, on the branchial rakers region (Fig. 1).

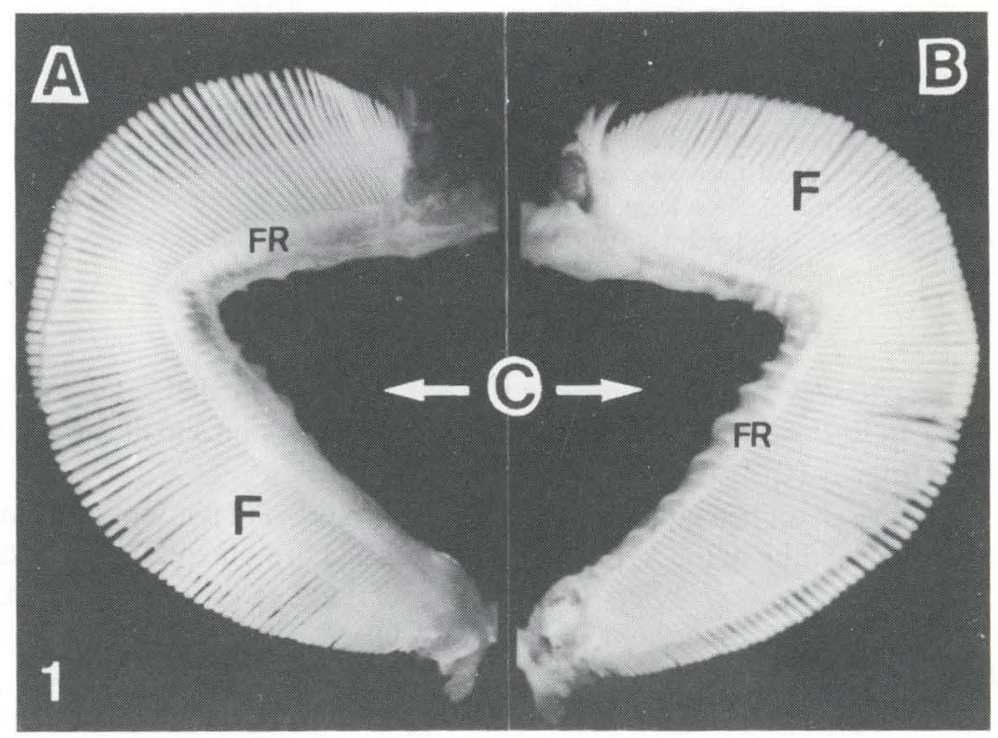

$4 \mathrm{~mm}$

Fig. 1. General aspect of the Prochilodus scrofa second branchial arch (Ball), light microscope photograph. (A) External side (it is the lateral side of the arch which faces the opercular opening); (B) internal side (it is the lateral side of the arch which faces the interior portion of the animal); (C) anterior side (it is the part of the arch which faces the mouth opening of the fish); (F) branchial filaments (formed by the primary lamellae and the secondary or respiratory lamellae); (FR) pharyngeal region (includes all structures of the arch, except the branchial filaments). 

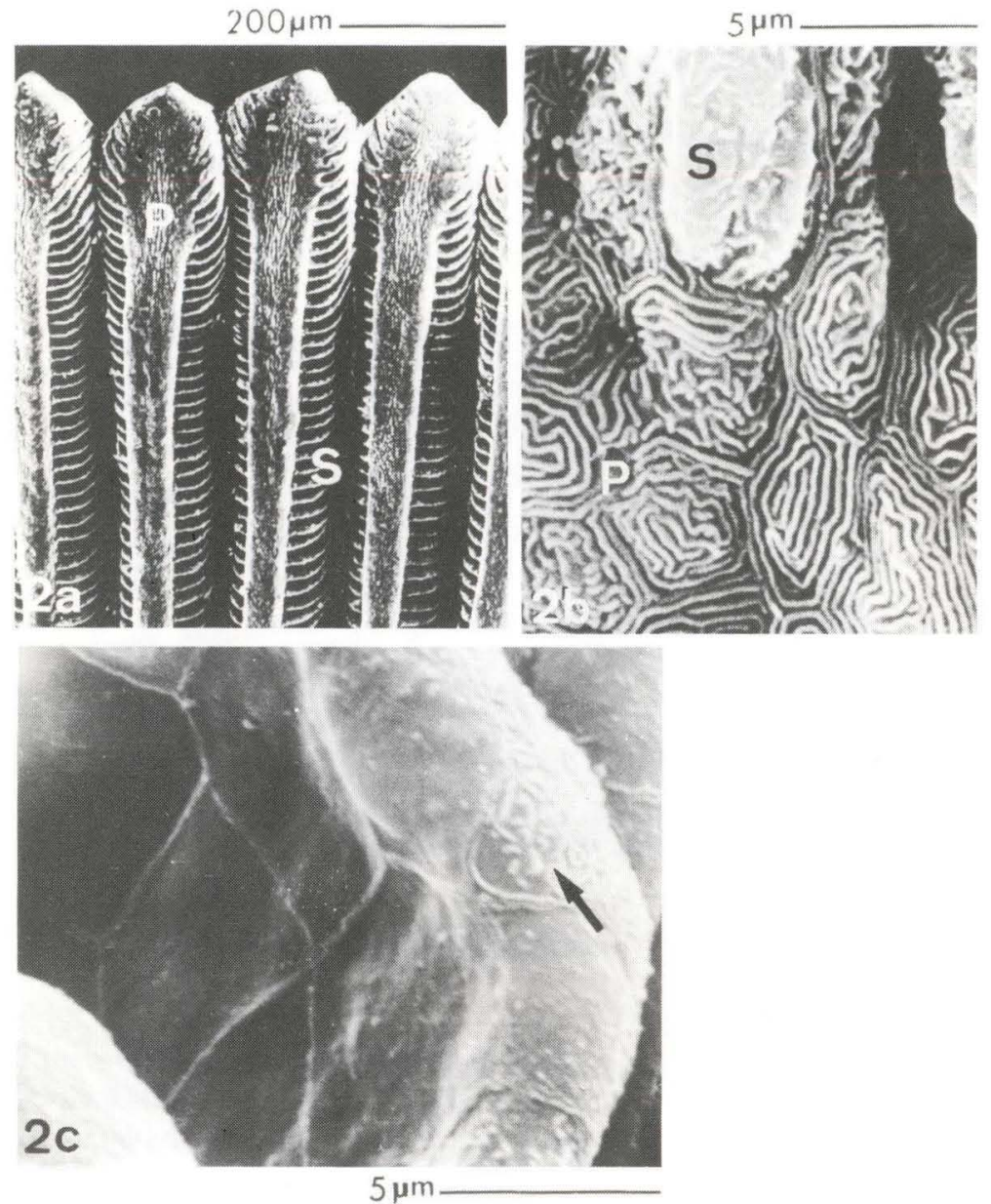

Fig. 2. Structures of the Ball branchial filaments of $P$. scrofa. (a) Primary and secondary lamellae on the distal portion of the filaments; (b) pavement cells of the primary lamellae on the transition region to the secondary lamellae; (c) secondary or respiratory lamellae showing the presence of microridges $(\rightarrow)$ only on the lamellar borders; (P) primary lamellae; (S) secondary lamellae.

\section{Branchial Filaments}

The branchial filaments are shorter on the extremities of the arch and in the strong curvature angle region (Fig.1). On the branchial filaments distal region, the primary lamellae abruptly turn wider and the secondary, or respiratory, lamellae have their size reduced (Fig. 2a).

The epithelium which covers the primary lamellae is formed by polygonal cells with salient microridges occupying all the cellular surface, even near the transition region with the respiratory lamellae (Fig. 2b). 
Several mucous and chloride cells (Fig. 3) were found along the primary lamellae, mainly on the distal portion of these filaments. On the other hand, on the secondary lamellae, mucous and chloride cells were not found.

The stratified epithelium of the secondary lamellae is formed by polygonal cells and the microridges predominate on the lamellar border cells, but even on this region their quantity is reduced and they are poorly defined (Fig. 2c).

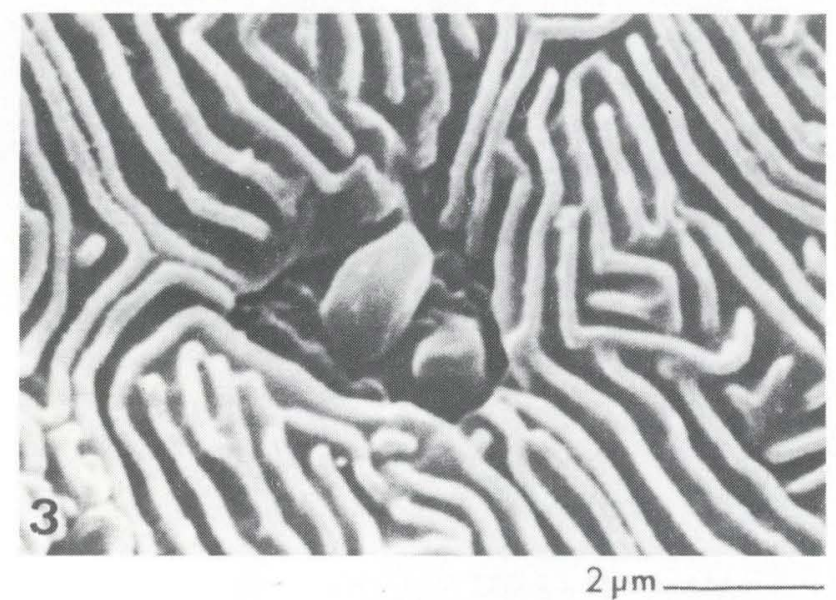

Fig. 3. Detail of a chloride cell of the primary branchial lamellae of $P$. scrofa.

\section{Pharyngeal Region}

The branchial arch pharyngeal region, where the gill rakers are found, presents morphological differences when the external (Fig. 4a) and internal (Fig. 4b) sides of a same BaII are compared. However, all gill rakers of this species are short.

Along all the external side of the branchial arch (Fig.4a) there are longer rakers alternated with shorter ones. On the region of the strong curvature angle of the Ball the gill rakers present a reduced size. Between the external side rakers of the arch many grouped spines are found (Fig. 4a,c).

Along all the internal side of the branchial arch (Fig. 4b) there are short rakers similar in size. However, it was observed the presence of an elongated protuberance which extends from a raker and contours the anterior side of the BaII until it reaches the proximities of the external side rakers. The following raker does not present this same elongated protuberance. This way, there is an alternate pattern on the distribution of this feature along all the BaII (Fig. 4a,b). The absence of spines on the internal side of the branchial arch was also observed.

Several taste buds (Fig.4a,b,5a,b) were found on the anterior part of the rakers (Fig. 5a), anterior part of the branchial arch (Fig. 4b) and also on the elongated protuberances positioned between the external and internal side of the Ba II (Fig. $5 b)$. 
The pavement cells of the BaII pharyngeal region have a clear borderline and salient microridges which are generally distributed along all cellular surface (Fig. 4c).

Mucous secretory cells are common in this region, mainly on the lateral side of the branchial arch, on the transition region between the base of the filaments and the rakers.

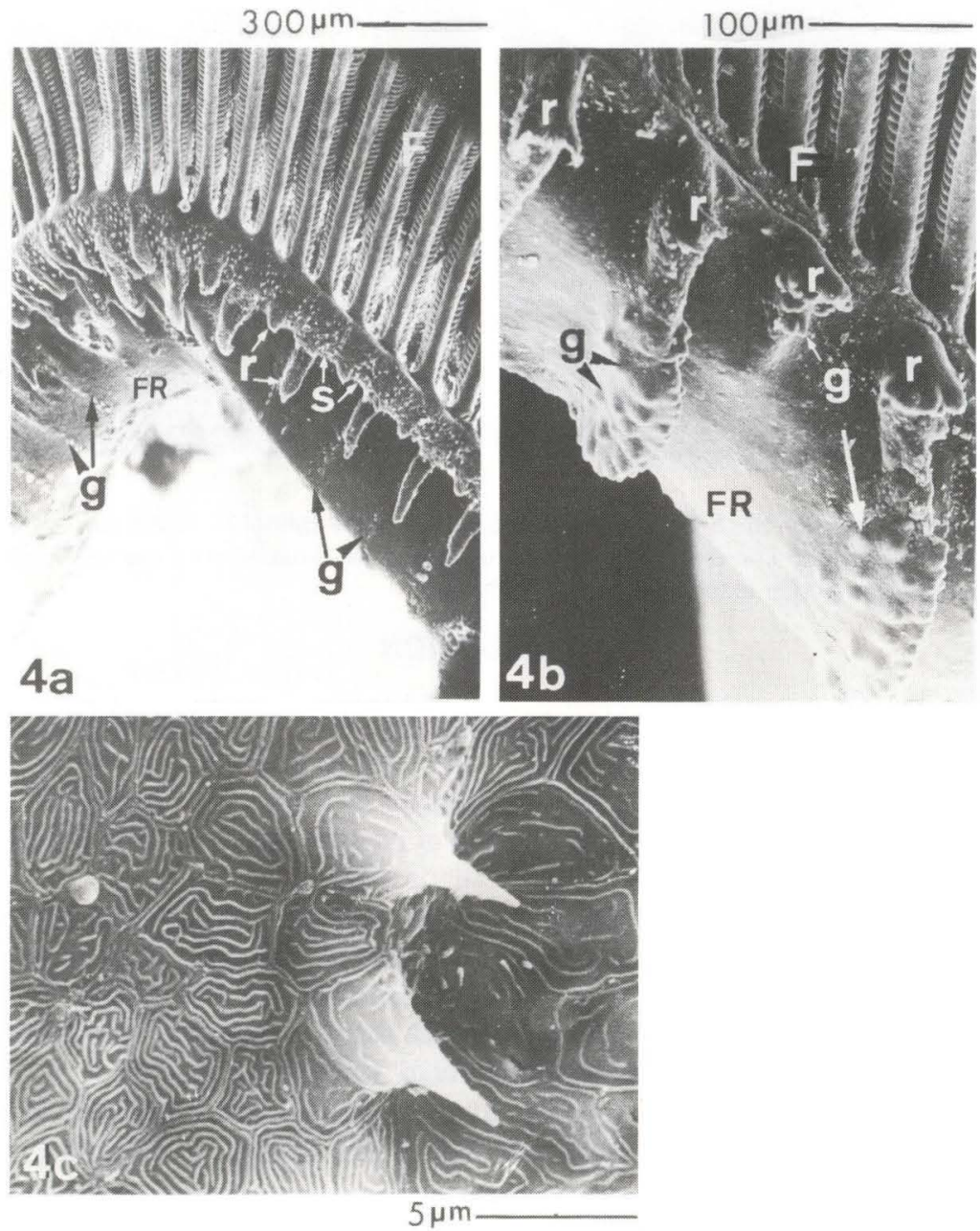

Fig. 4. Pharyngeal region of the Ball of $P$. scrofa. (a) View of the external side of the arch; (b) view of the internal side of the arch; (c) detail of the spines found exclusively on the external side of the branchial arch. (F) Branchial filaments; (FR) pharyngeal region; (r) raker; (s) spines; (g) taste buds. 

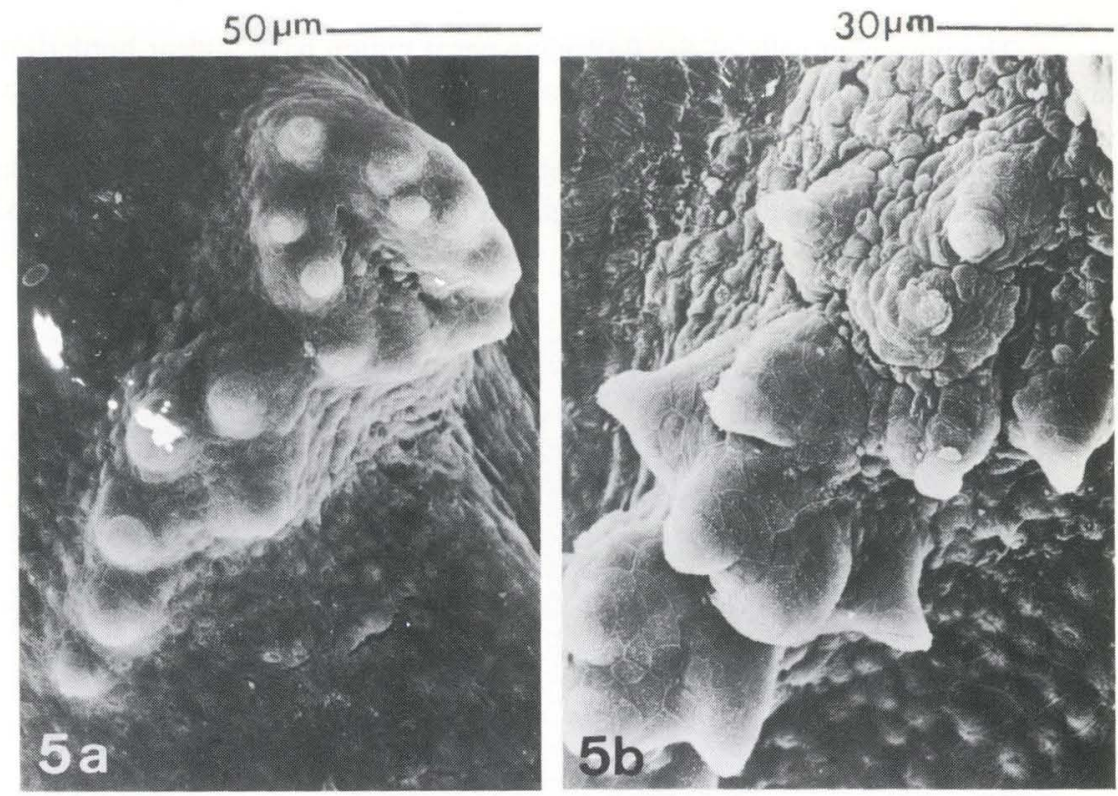

Fig. 5. Structures on the branchial pharyngeal region of the Ball of $P$. scrofa. (a) Taste buds on the anterior side of a branchial raker; (b) taste buds on a outstanding row which extends from the external side to the internal side of the arch.

\section{DISCUSSION}

The location and the shape of the gills of the fish P. scrofa are similar to most other Teleostei species. The branchial arches present a strong curvature angle on their superior third, where the branchial filaments are shorter and similar to the ones found on the dorsal and ventral extremities of the BaII (HUGHES 1984; FrANKLIN 1990; EIRAS-STOFELla \& CHARVET-ALMEIDA 1997).

The primary lamellae present a not very common characteristic which is a width increase on the distal portion of the branchial filaments. The absence of a gradual transition pattern related to the incidence of the microridges from the pavement cells surface of the primary lamellae near the secondary lamellae is also characteristic (HOSSLER et al. 1979; OJHA et al. 1987).

The presence of a great quantity of active chloride cells, located exclusively on the primary lamellae, indicates that this species presents an osmo-regulatory capacity.

The branchial secondary lamellae of fish are usually refered to as wrinkled structures, covered with pavement cells presenting few or no microridges (HOSSLER et al. 1979; OJHA \& MiSHRA 1993). These same characteristics were observed in $P$. scrofa, however, the secondary lamellae borders of $P$. scrofa present an intermediate morphological pattern between the primary lamellae (containing several microridges) and the secondary lamellae sides (containing very few microridges). 
The structural differences found on the branchial arches pharyngeal region of P. scrofa, when comparing the external and internal sides of a same arch, are common in Teleostei (EIRAS-STOFELLA \& CHARVET-ALMEIDA 1997).

The study done by EIRAS-STOFELLA \& CHARVET-ALMEIDA (1997), in which the pharyngeal region of several fish species were ultrastructurally compared, highlights the importance of the identification of this structure to understand the fish feeding habits. The short and not very sculptured branchial arch rakers of $P$. scrofa indicate that this species is not a filtering one. According to GoDOY (1975), $P$. scrofa is ilyophagous. The taste buds of $P$. scrofa, which are restricted to the pharyngeal region and turned towards the mouth opening of the fish, probably select the food to be swallowed by means of chemical receptors. The spines of the BaII external side and the mucous secretion possibly help in retaining the food.

The microridges commonly found on the branchial pavement cells of the fish are observed in a higher number on the primary lamellae and on the pharyngeal region of the branchial arches, where the quantity of mucous secretory cells is also higher (Hossler et al. 1979, 1985, 1986; HugHes 1979; FisHELSON 1980; EIRASSTOFELLA \& CHARVET-ALMEIDA 1997).

The wrinkling of the secondary lamellae and the reduced number or lack of microridges in these structures suggest problems on the gills processing (NEWSTEAD 1967; MORGAN 1974) or an efficient strategy of gas exchanges between the fish blood and the water environment (OJHA et al. 1987; OJHA \& MiSHRA 1993; EIRAS-STOFELLA \& CHARVET-AlmEIDA 1997). Several authors have tried to determine the function of the microridges and the mucous secretion which exist on the epithelium of specific structures (SPERRY \& WASSERSUG 1976; FISHELSON 1980; Whitear 1990; Avella et al. 1993, 1994; LUMSDEN et al. 1994; Kueltz et al. 1995; EIRAS-STOFElla \& CharVeT-Almeida 1997). The incidence, location and characterization of the mucous secretory cells and microridges of the branchial epithelium of $P$. scrofa leads one to believe that probably the main function of these structures is protection. The particles which enter through the mouth opening of the fish, and which had been previously selected by the taste buds, may be retained by the spread mucous on the channels formed between the microridges. This way, the secondary lamellae would be protected against the particles drag. They present a thinner epithelium probably due to the need of a greater proximity between the circulating blood in this region and the environment water in order to make the respiratory gas exchanges.

ACKNOWLEDGEMENTS. To Vera Regina Fontana Pionteke for her help with the photographic work in this paper and to the National Research Council of Brazil (CNPq) for the partial financial support.

\section{REFERENCES}

Avella, M.; J. Berhaut; M. Bornancin. 1993. Salinity tolerance of two tropical fishes, Oreochromis aureus and O. niloticus. I.Biochemical and morphological changes in the gill epithelium. Jour. Fish. Biol., London, 42: 243-254. 
Avella, M.; J. Berhaut; P. PAyAN. 1994. Primary culture of gill epithelial cells from the Sea Bass Dicentrarchus labrax. In Vitro Cell \& Dev. Biol. Anim., Rochville, 30 (1): 41-49.

Eiras-Stofella, D.R. \& P. Charvet-Almeida. 1997. Gills of the freshwater fish Hypostomus commersonii Val., 1840 (Loricariidae) analyzed through electron mycroscopy techniques. Arq. Biol. Tecnol., Curitiba, 40 (4): 785-792.

FISHELSON, L. 1980. Scanning and transmission electron microscopy of the squamous gill filament epithelium from fresh - and seawater adapted Tilapia. Environ. Biol. Fishes., Dordrecht, 5: 161-165.

FRANKLIN, C.E. 1990. Surface ultrastructural changes in the gills of sockeie salmon (Teleostei: Oncorhynchus nerka) during seawater transfer. Comparison of sucessful and unsuccessful seawater adaptations. Jour. Morphol., New york, 206: 13-23.

Godoy, M.P. 1975. Peixes do Brasil - Subordem Charachoidei. Bacia do Rio Mogi Guassú. Piracicaba, Franciscana, 4-8: 629-847.

Hossler, F.E.; J.R. Ruby; T.D. McIlwaIN. 1979. The gill arch of the mullet Mugil cephalus. I. Surface ultrastructure. Jour. Exp. Zool., New York, 208: 379-398. Hossler, F.E.; G. Musil; J. Karnaky; F.H. Epstein. 1985. Surface ultrasctruture of the gill arch of the Killifish Fundulus heteroclitus from seawater and freshwater, with special reference to the morphology of apical crypts of chloride cells. Jour. Morphol., New York, 185: 377 - 386.

Hossler, F.E.; J.H. Harpole; J.A. KING. 1986. The gill arch striped bass Morone saxatilis. I. Surface ultrastructure. Jour. Submicrosc. Cytol., Bologna, 18 (3): 519-528.

HuGHES, G.M. 1979. Scanning electron microscopy of the respiratory surface of trout gills. Jour. Zool., London, 187: 443-453.

1984. General anatomy of the gills, p.1-72. In: W.S. HOAR \& D.J. Randall (Eds). Fish Physiology 10A. New York, Academic Press, XXII+456.

Kueltz, D.; J. Juerss; L. JonAS. 1995. Cellular and epithelial adjustments to altered salinity in the gill and opercular epithelium of a cichlid fish (Oreochromis mossambicus). Cell. Tissue Res., Heidelberg, 279 (1): 65-73.

Lumsden, J.S.; H.W. Ferguson; V.E. Ostland; P.J. Byrne. 1994. The mucous coat on gill lamellae of rainbow trout (Oncorhynchus mykiss). Cell. Tissue. Res., Heidelberg, 275: 187-193.

MoraEs, M.F.P.G.; I.F. BARbolA; E.A.C. GuEdES. 1997. Alimentação e relações morfológicas com o aparelho digestivo do "curimbatá", Prochilodus lineatus (Valenciennes) (Osteichthyes, Prochilodontidae), de uma lagoa do Sul do Brasil. Revta bras. Zool. 14 (1): 169-180.

Morgan, M. 1974. Development of secondary lamellae of the gills of the trout Salmo gairdneri (Richardson). Cell Tissue Res., Heidelberg, 151: 509-523.

NEWSTEAD, D. 1967. Fine structure of respiratory lamellae of teleostean gills. $\mathbf{Z}$. Zellforsch. Mikrosk. Anat., Berlin, 79: 398-428.

OJHA, J. \& A.K. MisHRA. 1993. Interespecific variations in the functional organization, dimensions and scaling of gills in relation to body weigth of the gangetic 
mullets, Rhinomugil corsula (Ham.) and Sicamugil cascasia (Ham.) (Mugilidae, Mugiliformes). Proc. Indian Nat. Sci. Acad. Part B: Biol. Sci., Calcuttá, 59 (6): $567-579$.

OJHA, J.; A.K. Mishra; J.S.D. MunSHI. 1987. Interespecific variations in the surface ultrastructure of the gills of freshwater mullets. Jpn. Jour. Ichthyol., Tokyo, 33 (4): 338-393.

SPERRY, D.J. \& R.J. WASSERSUG. 1976. A proposed function for microridges on epithelial cell. Anat. Rec., New York, 185: 253-258.

WHITEAR, M. 1990. Causative aspect of microridges on the surface of fish epithelia. Jour. Submicros. Cytol. Pathol., Bologna, 22 (2): 211-220.

Recebido em 28.II.1997; aceito em 17.IV.1998. 